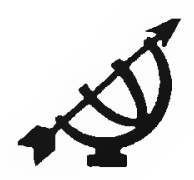

\title{
A reflection on perspectives on multiculturaiity in South African higher education
}

\author{
Laetus O.K. Lategan \\ Executive Assistant of the Principal \\ Technikon Free State \\ BLOEMFONTEIN \\ E-mail: llategan@mail.tofs.ac.za
}

\section{Abstract}

A reflection on perspectives on multiculturality in South African higher education

The South African higher education system is facing dramatic new changes. One of the most challenging issues is that of multiculturality. Multiculturality in higher education exists next to other challenges such as a new National Qualifications Framework; quality assurance initiatives; an Act on Higher Education in which a new social and academic role is given to higher education; the massification of the university system; increased access to higher education by former disadvantaged students; and the emphasis on social and human development by means of higher education programmes. This article will reflect on the way in which multiculturality should be understood within the new context of higher education in South Africa.

\section{Challenges of a South African higher education system}

The South African higher education system is characterised by dramatic changes ranging from a paradigm shift from teaching to learning; a new higher education system documented in a Higher Education Act 101 of 1997; a new qualifications Act for Education (Act 58 of 1995); massification of the system by especially students coming from disadvantaged backgrounds; limited funding; the integration of cultures (including language and ethnicity) within higher education; as well as affirmative action with a view to capacity-building and transformation. These changes as well as other are informed by national and international developments. 
A reflection on perspectives on multiculturality in South African higher education

Seen from a higher education point of view, all these developments are of equal importance. In this article the focus will be on one of these new developments, namely multiculturality. This article will highlight multiculturality in the context of higher education institutions and propose a way in which multiculturality might be addressed. It will also point out some ideological problems attached to the understanding of multiculturality. A practical example will explain the need for the successful handling of multiculturality. The article concludes with a perspective on the role that multiculturality can play within the context of a new university system.

\section{Multiculturality as a particular challenge in South African higher education}

Although multiculturality is in principle not a new reality (Van der Walt, 1997), it is an ever increasing reality in South African higher education. Within the higher education - as well as other structures of society - the problem is how the uniqueness of each culture can be maintained in the face of multiculturality. Appropriate examples are the accommodation of different cultural groups in traditionally Afrikaans, English and black higher education institutions, and demands such as that only that which is inherent in (unique to) a culture, may be studied (thus - no Shakespeare studies in African higher education). Ensuing from these challenges, the question is whether it implies discrimination to uphold the uniqueness of each culture at the cost of the diversity of cultures. One can also ask if the contrary is not also true.

\section{How to deal with multiculturality in South African higher education: a possible solution}

Academics and students differ on the handling of multiculturality. One suggestion is to draw up an agenda of the different cultures which can be regarded as a reference for ways in which people of different cultures should behave towards each other. The problem with this suggestion is that a difficulty could arise which was not provided for in the above-mentioned agenda - how do people behave towards each other then? To determine such a state of cultural affairs would also be a time-consuming process. The problem of cultural diversity will have to be approached from another angle. A possible solution - even if it is partial only would be to emphasise that which is common to all the different interest groups. Diversity is therefore seen from a communal angle.

Within the context of higher education, which is traditionally characterised as an institution of higher learning, learning is the common factor. The objective should therefore be to establish a learning community. Learning is the one thing that all students have in common, regardless of their cultural background (Lategan, 1994; 
Lategan \& Bekker, 1996; Lategan \& Visagie, 1996; Lategan, 1997). From this perspective an attempt should then be made to counteract the individual and interactive factors that impede higher education. This primary focus will influence the attention paid to education, research, human relations, curriculum development, as well as academic development services and programmes.

A learning community refers to the way in which attention is given to education (teaching and learning), research, human relations (between staff members, between students, and between staff members and students), curriculum development, academic support services and programmes, administration, and development programmes for staff, students and the community. Emphasising a learning community would contribute to the addressing of problems linked to multiculturality from the angle of an academic culture. In practice this means that an academic environment must exist. In this environment students will have the opportunity to minimise their cultural differences and to maximise that which the staff and students have in common - to master knowledge and to prepare to meet the challenges of reality outside the field of higher education

In this article it will therefore be argued that in a higher education community, where specialised research (both theoretical and applied) and tuition (learning as overall perspective) are practised, students, lecturers and other staff members all have learning in common. This perspective should be emphasised as the hinge between the reality of multiculturality and the changing image of higher education. It is not possible to implement a multicultural environment if this is interpreted as the accommodation of different cultures. This will mean, in practice, that the difference is emphasised and not that which is general (common) to a higher education community. It should perhaps be recommended to adhere to that which is a general feature of the higher education community, rather than to lay emphasis on the differences. The foundation of this logic is the philosophical notion that unity includes diversity and vice versa (Strauss, 1980:24)

\section{Ideological formations attached to the concept of a learning community}

A thorny issue within the learning community is the issue whether a particular culture should be emphasised within the context of multiculturality.

Giving preference to one culture (for example the Afrkaner culture) as norm for other cultures, is cultural élitism. To say that culture plays no part at all, is cultural relativism. The denial that a student's culture can play a role in his education, is cultural pluralism (Visagie, 1993:78-9, Visagie \& Pretorius, 1993: 56-8). One should therefore be very careful not to give the learning community an ideological "face". 
Multiculturality can become an ideology if it is the only cultural strategy. For the purpose of this article, ideology implies the following: When a premise is taken from reality and becomes an explanation of reality, it can be seen as an ideology (see Visagie, 1990). Within the context of a learning community, there is ample room for an ideology to flourish. In this regard, think of for example, the concept volk (nation). If the concept of volk becomes absolutised and everything else in reality is understood / explained in terms of it, volk (nation) becomes an ideology. Examples are notions such as volk church, volk higher education, volk sport. Degenaar (1977:149) aptly explains the concept of volk. He argues that, as the concept volk has a higher identity than the individual, it is assumed that the individual finds his own identity by identifying himself with the volk and its unique virtues. A weaker version of this would be that volk has a unique (Godgiven) identity and that the individual fulfils his own identity by identifying with the unique identity of the volk. In practical terms this means that the interests of the volk are put first - these interests are decisive with regard to the rest. Thus the interests of the volk will weigh more than academic principles in the case of a volks higher education. An example which clarifies the concept of ideology within the educational context better, is the distinctive demands of Christian national education (as influenced by the Dutch Reformed Church and the National Party) and people's education.

The conclusion is clear: Multiculturality can become an ideology if it is the only cultural strategy. For this reason it is important to emphasise cultural uniqueness in juxtaposition to cultural diversity.

The question now arises whether cultural unity is beyond ideological formations. Such a statement would, however, pose a problem. Cultural unity often results in the "salad bowl" and "melting pot" metaphors. Within the context of the "salad bowl" and the "melting pot" metaphors there is no room for different cultures, except the unifying culture. This strategy will once again lead to an ideology.

Seen from a Christian point of view, all people are created in the image of God. People here include race, sex, culture, etc. Genesis 1:26 nowhere states that the image of God is reserved for a specific race, sex or culture. Paul confirms this when he writes that there is no difference between Jews and Greeks (Galatians 3:28). The image of God implies that we cannot decline people or their cultures. People are what God created them according to.

\section{A learning community accommodating multiculturality in higher education}

There is general agreement that access to learning communities should be granted to more students - especially those coming from disadvantaged backgrounds. By implication it also means students from other cultures. Another viewpoint which 
exists next to a broader access policy is that standards should not be dropped or lowered regardless of the cultural background of students. Higher education institutions should therefore work towards the opening up of access as well as the introducing of measures to improve the standards of programmes. This calls for quality in all the access activities of higher education. If quality access is not "right sized", students will simply not succeed. This approach is also at odds with the Christian point of view that all people should be helped to reach their full potential. Means should be created to activate mechanisms to secure access with success.

Quality access policies are crucial to safeguard access policies from becoming marionettes of populist demands instead of serious initiatives to improve access to programmes and to develop the idea of a learning community. There should therefore be a relationship between quality (generally understood as fitness for purpose - Harvey, 1995) and access. Bergquist (1995:xi) states that in the USA considerable attention has been given to access and quality during the past century. Since education is regarded as a guarantee for social and economic gains, access and quality are mechanisms to ensure it. Four perspectives on quality can be put forward. Each of these perspectives has an effect on access policies. These policies can only be changed once the foundations of these policies are known (Bergquist, 1995:99-210):

- The élitist perspective creates high-status institutions. In this respect mission is unimportant, boundaries are unclear and a close interrelationship between education and the moulding of a moral character exists.

- The populist perspective meets two challenges, namely practicality and equity. Populism is in contrast to elitism and these values should be seen as conflicting. Where the élitist perspective is directed at the community, the populist perspective, with the emphasis on the individual, becomes more important than the concern for society and community. In a populist institution attention is paid to admission standards and the evaluation of student performance - the nature of quality is not given much thought.

- The beleaguered perspective is the result of institutions facing problems of declining enrollment, inadequate funding and diminishing public support. Within this perspective the interplay between access and quality is a moot issue. Fragmentation is at the order of the day, therefore the mission of an institution can hardly be operationalised.

- Although there is a willingness in the expedient perspective to try out new ideas and take risks, these new ideas are not necessarily related to the mission of the institution. This perspective offers clarity on the short-term goals of the 
institution but there is uncertainty about the overall mission of a school, especially as it relates to new programme initiatives.

Quality improvement - at the institutional and programme levels - is necessary, not only to continuously strive towards academic excellence, but also to prevent quality deterioration. To make "improvements" instead of merely "changes", one needs to know which independent variables are related to the dependent variable(s), in which way and why. Within the context of a learning community it is important to understand that one will deal with students coming from various backgrounds which will necessarily have an impact on the activities of the learning community. Very often the analysis of this situation tends to become very technical (as illustrated above) and many people will enquire into the relevance of such a technical debate for higher education and in particular Christian higher education. Nobody can deny the fact that access has to do with more than getting the student through the system. Access is not only institutionally defined (can the student get entry to the various services of the institution, can the institution deliver quality people? etc.) but also is anthropologically defined (what value are added to the student?). Within a Christian philosophy of education, every aspect should focus on the individual as image bearer of God in the development of the individual. The university's role in culture is continuously subject to scrutiny. It is expected of higher education institutions to contribute to the total development of the student. These institutions may very well accomplish this in an academic way - but never as a venture (commitment) besides teaching and research. Seen against the background of the qualification function of a higher education institution, the cultural development of a person is strictly spoken, needless as "additional" task, as the developed (opened) logical mind already intrinsically harbours cultivation and an appeal to development

... cultivation at a university should be different from cultivation in the family or the church. Education at the university is always related to scientific endeavour ... the university has many functions. In university education these functions will also come into account ... all these matters are inextricably related to the typical function of the university. The typical function is also internally related to the ... functions of the university, cf. the phenomena of thought communion (the logical intercourse with divergent viewpoints), logical symbolism (intrinsically logical language by means of a symbolic system), logical economy, etc. Internal development of logical thought too, in terms of this and other functions, has a cultivating nature (Visagie, 1980:158).

What is important to take into account is that Christian higher education cannot simply ignore the developments occuring at the moment. Christian institutions do not exist in isolation from other institutions. Christian institutions, however, differ from other institutions in their approach to reality. This approach has to be reflected in the establishment of a learning community at a Christian oriented 
institution. In analysing the different access policies and their relation with quality, it is recommended that the quality of these policies should reflect both the institutional and the anthropological aspects of education.

\section{The role of multiculturality within a new higher education system}

In reviewing the new social and global context of the higher education, as well as the new policy formulations as regards higher education, the following role for multiculturality within the learning community is suggested:

- In many countries higher education has been seen as ivory towers functioning within a community but with no real significance or benefit for the problems and the development of the communities themselves. Science has been practised for the sake of science and for no other particular reason. This exclusivity has given rise to many negative effects, and it has become obvious that the dichotomy between vocational and academic general-formative education should be eliminated, or at least largely attenuated. Both types of education must be provided for at all educational levels, and no distinction needs to be made between the educational and human development goals which should guide them. We cannot simply divorce the educational and human development from one another since these aspects are interwoven in reality. Isolation does not serve the needs of people or the society in which they work. Exposure to numerous viewpoints without a critical perspective on these viewponts is part of a neutralistic science belief which is at odds with the Christian idea of groundmotives underlying the various scientific paradigms.

- To a large extent the articulation between various cultures very often depends on the specific socio-economic and educational contexts and traditions of each group. Discrimination between culture groups should be avoided at all time. Difference in culture does not mean that we should treat people differently Within a learning community all people should be treated the same. This means, for example, that higher education accommodating Christian cultures, should be prepared to enroll students from other cultures than the Christian culture without biding their particular culture farewell in order to become a melting pot in which there is no room for a particular world and life view.

- Acquiring and managing resources to the benefit of the student should make them cost-effective for both the funder (the government, taxpayers, industries, funding agencies, etc.) and the client (students who have to enrol in the system). 
- Higher education should contribute towards the workforce. In doing so students should learn how to deal with problems of the working community. We need skilled people who have an economic worth wherever they are deployed. Too often in the past it happened that learning institutions trained people to be job-specific instead of context- and market-specific. The new economical framework requires that people should bring their skills in the marketplace and that these skills should be compatible in any context. This approach requires that the idea of globalisation should be taken into account when the curricula of higher education are designed. Higher education functioning from a particular worldview should communicate with other cultures as well since no culture can exist in isolation.

- Traditionally, higher education has been associated with the notion of distinctiveness, of something special or high-class. This notion of higher education implies exclusivity. A problem with this approach is that within a developing society, the notion of exclusivity does not offer yardsticks against which to measure the needs of higher education such as equity, capacitybuilding, quality and skills development. Higher education has to change in order to meet the demands of a developing society. The traditional notion of higher education can only really be applicable in a homogeneous situation, where consensus exists on what the standards are and what the purpose of a learning community is. The particular worldview underlying a particular culture will have an effect on the communication that takes place within and outside the learning community.

\section{References}

AFRICAN NATIONAL CONGRESS 1994 The Reconstruction and Development Programme: A policy framework. Johannesburg : Umanyano Publications

BERGQUIST, W B. 1995. Quality through access, access with quality. The new imperative for Higher Education. San Francisco : Jossey-Bass Publishers

DEGENAAR, J. 1977. The concept of a Volksuniversiteit. (In Van der Merwe, H W \& Welsh, D eds. The future of the university in Southern Africa. New York : St. Martin's Press.)

HARVEY, L. 1995. Editorial Quality in Higher Education, 1(1):8-12.

LATEGAN, L O K 1994. Physical planning in a multicultural higher education environment (In Van der Walt, A. ed. The principles for multicultural tertiary education Vanderbijlpark: Vaal Triangle Technikon p. 98-101.)

LATEGAN, L.O.K 1997. Should the concept of a learning community be the nucleus of a multiculturality programme of a higher education? A critical appreciation of the notion of a learning community. Paper read at a multicultural conference on "Unity within diversity: Maximising learning on South African campuses" Bloemfontein. 16-18 March.

LATEGAN, L O K \& BEKKER, J C O. 1996 A world without bounds: Managing cultural diversity for citizen participation. (In Bekker, J.C.O ed. Citizen participation in local government Pretoria: Van Schaik p 109-119.) 
LATEGAN, L.O.K \& VISAGIE, P.J. 1996. Multikulturaliteit binne die universiteit Teoretiese en operasionele perspektiewe vanuit die Filosofie en die Hoër Onderwys (In Bitzer, E.M. red. Perspektiewe op multikulturaliteit/ Perspectives on multiculturality. Bloemfontein : Higher education Publishers. p. 54-70.)

STRAUSS, D F.M 1980 Inleiding tot die kosmologie Bloemfontein : Sacum

VAN DER WALT, B.J. 1997. Afrosentries of Eurosentries? Ons roeping in 'n multikulturele Suid-Afrika Potchefstroom : Instituut vir Reformatoriese Studies

VISAGIE, P.J. 1980. University or multiversity. Tydskrif vir Christelike Wetenskap, $14(3 / 4): 153-165$

VISAGIE, P.J. 1990. The mission of the higher education in a critique of culture. Acta Academica, 22(1):114-134

VISAGIE, P.J. 1993. Quality, equality and relations of dominations in society, culture and cognition. South African Journal of Higher Education, 7(2):75-82.

VISAGIE, P.J. \& PRETORIUS, JL. 1993. The ideological structure of the minority rights discourse in South Africa. SA Public Law, 8(1):53-67. 